\title{
マルチモーダルLDA と NPYLMを用いた ロボットによる物体概念と言語モデルの相互学習 Mutual Learning of an Object Concept and Language Model Based on MLDA and NPYLM
}

\author{
中村 友昭 \\ Tomoaki Nakamura \\ $\underset{\text { Takayuki Nagai }}{\text { 長行 }}$ \\ 船越 孝太郎 \\ 谷口 忠大 \\ $\underset{\substack{\text { 岩橋 直人 } \\ \text { Naoto Iwahashi }}}{ }$ \\ 金子 正秀
}

電気通信大学大学院 情報理工学研究科 知能機械工学専攻 tnakamura@uec.ac.jp

(同上)

tnagai@ee.uec.ac.jp

株式会社ホンダ・リサーチ・インスティチュート・ジャパン

Honda Research Institute Japan Co., Ltd.

funakoshiejp.honda-ri.com

立命館大学 情報理工学部 知能情報学科

Department of Human and Computer Intelligence, Ritsumeikan University

taniguchidem.ci.ritsumei.ac.jp

岡山県立大学情報工学部情報通信工学科

Department of Information and Communication Engineering, Okayama Prefectural University iwahashi@c.oka-pu.ac.jp

電気通信大学大学院 情報理工学研究科 知能機械工学専攻

Department of Mechanical Engineering and Intelligent Systems, Graduate School of Informatics and Engineering, The University of Electro-Communications kaneko@ee.uec.ac.jp

keywords: MLDA, NPYLM, object concepts, language acquisition, symbol grounding, robot

\section{Summary}

Humans develop their concept of an object by classifying it into a category, and acquire language by interacting with others at the same time. Thus, the meaning of a word can be learnt by connecting the recognized word and concept. We consider such an ability to be important in allowing robots to flexibly develop their knowledge of language and concepts. Accordingly, we propose a method that enables robots to acquire such knowledge. The object concept is formed by classifying multimodal information acquired from objects, and the language model is acquired from human speech describing object features. We propose a stochastic model of language and concepts, and knowledge is learnt by estimating the model parameters. The important point is that language and concepts are interdependent. There is a high probability that the same words will be uttered to objects in the same category. Similarly, objects to which the same words are uttered are highly likely to have the same features. Using this relation, the accuracy of both speech recognition and object classification can be improved by the proposed method. However, it is difficult to directly estimate the parameters of the proposed model, because there are many parameters that are required. Therefore, we approximate the proposed model, and estimate its parameters using a nested PitmanYor language model and multimodal latent Dirichlet allocation to acquire the language and concept, respectively. The experimental results show that the accuracy of speech recognition and object classification is improved by the proposed method.

1.は じめに

事物のカテゴリ分類は, 人間の認知機能において重要 な役割を果たしていることが指摘されている．人間はカ テゴリを形成することで, 経験した物事を全て参照する ことなく, 必要最小限の認知的処理によってより多くの 情報を得ることができる [Rosch 99]．また，カテゴリ分 類の重要性は, 経験を通して形成したカテゴリを利用し た予測が可能な点にある.人は , 未知の物事に対しても
カテゴリを通して樣々な予測を行い, 柔軟に対応してい る.このようなカテゴリは知覚可能な樣々な情報を分類 することで形成することができ，本論文では光のような カテゴリが概念であると考える.さらに，弚のような概 念と単語が結びつくことで, 我々は単語の意味を理解す ることができる [Smith 05] . すなわちロボットにおいて も，このような経験をカテゴリ分類する能力を持つこと は非常に重要であると考えられる .

乥こで著者らは，これまでLatent Dirichlet Allocation 
(LDA)[Blei 03] を拡張したマルチモーダルカテゴリゼー ションを提案し，複数のモダリティを用いることによ り，より人間の感覚に近いカテゴリを形成することが 可能となることを示した [Nakamura 12] .さらに，形成 されたカテゴリが概念であると考え，単語を概念に接 地することで語意の獲得を可能とした . 人の発話を音 節認識器で認識し, Nested Pitman-Yor Language Model (NPYLM)[Mochihashi 09] を用いて教師なしで音節列を 単語に分割し, 切り出された単語を概念と結びつけるこ とで, 弚の語意の学習が可能となった [Araki 12] . 提案 手法は確率モデルに基づいており，学習したグラフィカ ルモデルを用いることで, 未学習物体のカテゴリ認識が 可能である．さらに，学習したモデルを用いて，未観測 の情報である単語を推定することを可能とした，我々は， 弚のような推定が事物の理解につながると考えている .

しかし, これまでの研究では単語分割において言語モ デルであるNPYLM を扱っていたものの，音声の認識に は音節認識のみを用い，言語モデルは扱っていなかった 。 言語モデルは単語間のつながりを確率的に表現したモデ ルであり，言語モデルを用いて認識可能な単語を限定す ることで, 高精度に音声認識をすることが可能である．し かし，これまでの音節認識のみを用いた手法では，すで に学習された単語であっても，言語モデルを持たないた めに異なる音節列として認識されるといった問題があっ た . 弚のため，学習することで物体概念は形成できるが， 物体名を正しく認識できず，またロボットの発話も誤り が多いものであった . 言語と概念は密接に関わっており， これらを同時に学習できれば, 音声認識の精度を向上さ せることができ，さらに誤りの少ない物体概念の形成が 可能となる . 本論文の目的は , このような言語モデルを あらかじめ与える (音声認識器に付属の言語モデルを使 用する) のではなく，この言語モデルも教師なしでロボッ 卜が自律的に学習することである．乥こで，これまでの マルチモーダルLDA (MLDA) を拡張することで, 言語 モデルと物体概念を相互に学習可能なモデルを提案する． 図 1 が提案手法の概要である.ロボットは, 物体から取 得可能なマルチモーダル情報と, 兴の物体の特徵を教示 するユーザ発話から物体概念と言語モデルの学習を行う 教示音声は言語モデルを用いて，文字列へと変換される． さらに，この文字列は物体の特徵を表しているため，物 体のマルチモーダル情報から形成される物体カテゴリか らも生成される。ここで重要なことは, 単語はロボット が形成した概念を意味しており，単語と概念が独立して いるのではなく相互に関係している点である .すなわち， 同じカテゴリに含まれる物体には, 同一の単語が与えら れる可能性が高く，また逆に同じ単語が与えられた物体 は, 共通する特徵を有している可能性が高いといえる.ロ ボットは概念と言語モデルを学習する際に，このような 情報を利用することで, 音声認識の精度と分類精度の両 方を高めることが可能となる．しかし，言語モデルと物

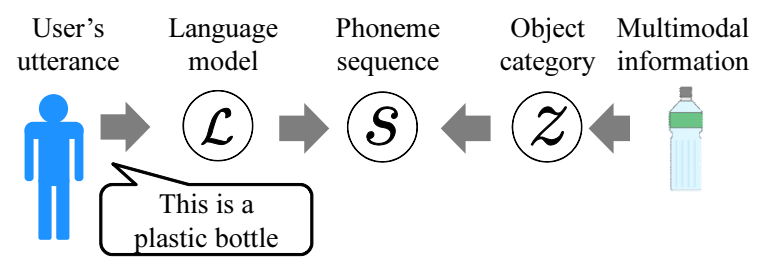

図 1 提案手法の概要

体概念を同時に学習することは，推定すべきパラメータ が多く計算することが困難となる，光こで，本論文では， 図 1 のモデルを近似することで計算を可能にする .以下 に従来手法と，本論文て提案する手法についてまとめる．

MLDA [Nakamura 12]＼cjkstart言語モデルを使用した音声認 識器を用いており，厳密な意味で教師なし学習では なかった。

MLDA+NPYLM [Araki 12] 音節認識した結果を教師 なしで単語へ分割することで, 言語モデルを持たな くとも単語の獲得が可能となった。しかし，言語モ デルを持たない音節認識器を使用したため，学習さ れた単語には多くの誤りが生じた

提案手法 音声認識器に用いる言語モデルも教師なしで 学習を行うことで, より精度の高い音声認識を実現 し，前述の問題を解決する。

これまで概念と言語や単語を同時に獲得する研究 [Roy 02, 田口 10] も行われているが , 本論文のように視覚・聴 覚・触覚・言語といった多数のマルチモーダル情報から 物体概念と言語を獲得する研究は行われていない . [Roy 02]では, 音響の類似性とロボットが見ている物体の類似 性から, 物体と弚の名前の学習を行っている。しかし, 連 続音声からの単語の分節化精度は $30 \%$ 程度であり，また 言語モデルの学習は行われていない . [田口 10] では場所 の名前を獲得することが目的であり，また言い回しのパ ターンを固定して実験をしている。一方，本論文では自 由な言い回しの教示発話から分節化した単語と, ロボッ 卜が取得可能な視覚・聴覚・触覚情報から物体概念と言 語モデルを獲得する．

また，マルチモーダル情報間の関係を学習する研究も 行われている [Wermter 04, Ridge 10, Ogata 10, Lallee 13, Mangin 13] . これらの研究では, 人から与えられる 言語や，ロボットが取得可能な視覚情報，ロボットの動 作等の関係性を学習することで, モダリティ間の相互の 予測をすることが目的であり，本論文のように概念・言 語獲得は行っていない.

さらに,カテゴリ分類に関する関連研究として, 視覚情 報のみを用いた物体カテゴリの教師なし学習に関する研 究がある [Sivic 05, Fergus 03, Fei-Fei 05, Wang 09] .さ らに近年では,レーザーレンジファインダーや TOF カメ ラから取得できるポイントクラウドを用いてカテゴリを 教師なしで学習する研究も行われている [Endres 09] . し 


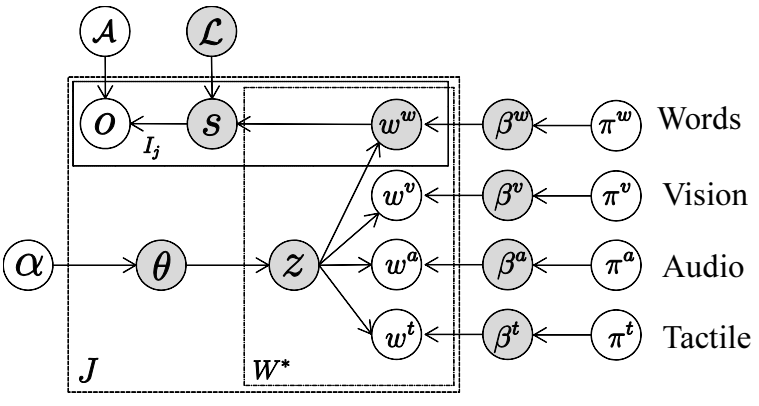

図 2 言語と物体概念のグラフィカルモデル

かし，視覚情報のみでは形成できないカテゴリも存在す る、また，ロボットが物体に触れた際の音を用いた研究 も行われている [Sinapov 11] . この研究では, 音を利用 することで視覚情報だけでは形成することが困難なカテ ゴリを形成することができることを示している．しかし， この研究ではカテゴリの形成と認識を行うことが目的で あり，本研究のように未観測情報の予測や言語の獲得な どは考えられていない.さらに, ロボットの触覚センサー を用いた研究もいくつかなされている [Natale 04, Russell 00, Schneider 09] . しかし, これらの研究では, 触覚を 用いて物体や光の形状を認識することが目的であり，物 体のカテゴリは考慮されていない .このように，視覚・ 聴覚・触覚を個々に使用した研究はいくつもなされてい るが，人間がカテゴリ分類する際には単一のモダリティ だけではなく，複数のモダリティを用いているため，よ り人間の感覚に近い分類を実現するためにはマルチモー ダルな情報が必要である [Smith 05] .

\section{2. 言語と物体の統合モデル}

图 2 は, 言語と物体概念を統合したグラフィカルモデ ルであり，灰色で示されたノードは未観測ノードを表し ている.図中のoが人から教示される音声である .この音

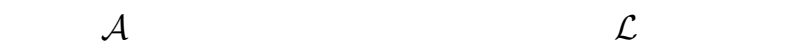
タとする言語モデルにより認識した結果が $s$ である .さ らに, 認識結果 $s$ を言語モデル $\mathcal{L} を$ 用いて単語へ分割 し, Bag of words(BoW) 表現へと変換したものが単語情 報 $w^{w}$ であり，さらに， $w^{v}, w^{a}, w^{t}$ は光れ光れ物体か ら得られる視覚情報, 聴覚情報, 触覚情報を示している. 各情報の詳細については後で述べる．また $z$ は物体の力 テゴリを表している.さらに， $w^{v}, w^{a}, w^{t}, w^{w}$ は, 弚 れ光れ $\beta^{v}, \beta^{a}, \beta^{t}, \beta^{w}$ をパラメータとする多項分布か

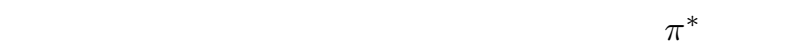
メータとするディリクレ事前分布に従う．また，カテゴ リ $z$ の出現確率分布を表す多項分布のパラメータを $\theta$ と する.このパラメータは, ハイパーパラメータ $\alpha$ にり 決まるディリクレ事前分布に従う. $J, W^{*}, I_{j}$ は, 弚れ光 れ物体数, モダリティ*の情報の生起回数, $j$ 番目の物体 への教示発話数を表している.

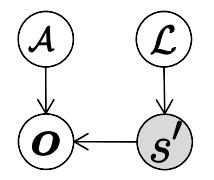

(a) Speech recognition

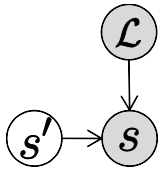

(b) Language model

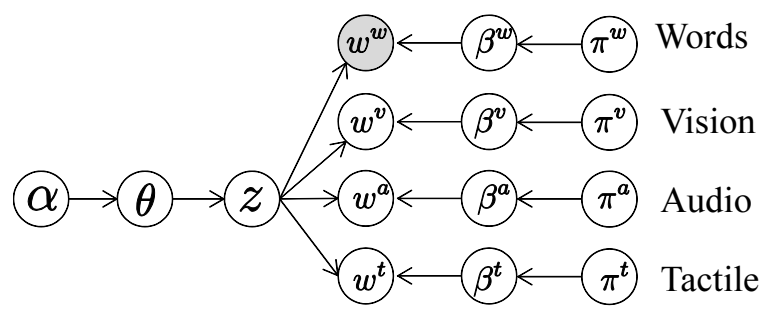

(c) Word candidates selection

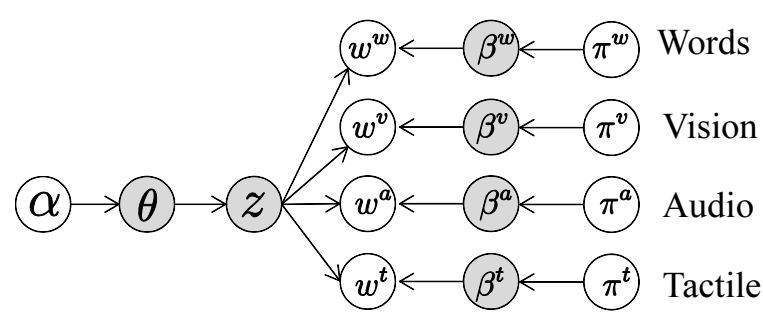

(d) Object concept

図 3 言語と物体概念の近似モデル

このモデルでは, 音声認識結果 $s$ と物体カテゴリ $z$ が 単語 $w^{w}$ によって接続されているため, 音声認識と物体 概念形成が相互に影響するモデルとなっており，音声認 識・単語の接地・概念獲得などか統合されたモデルとなっ ている. 言語モデル・物体概念獲得は, 可観測ノードで ある音声 $o$ と視覚・聴覚・触覚情報 $w^{v}, w^{a}, w^{t}$ から， パラメータ $\mathcal{L}, \beta^{*}, \theta$ を推定し, 隠れ変数である音声認識 結果 $s$, 単語情報 $w^{w}$, 物体カテゴリ $z$ を決定することで 可能となる.しかし, このモデルは複雑なため, 一度に 全てのパラメータを求めることは困難である .

乥こで本論文では，このモデルを 4 つのモデルへと分 割し, 各モデルのパラメータを逐次推定することで学習 する手法を提案する .このモデルは, 音声認識・言語モ デル学習・単語候補選択・物体概念モデルの 4 つに分割 することができ，各モデルは光れ 3(a)〜 (d) のよう になる . 図中の灰色のノードが末観測の推定すべきパラ メータを示しており, 適当な初期值から始め, 以下の手 順を繰り返すことで各パラメータの推定を行う．

\section{1. 音声認識}

図 3(a) が音声認識のモデルである .ここでは音響モデ ルのパラメータ $\mathcal{A}$ と言語モデルのパラメータ $\mathcal{L}$ は既 知とし，全物体になされた全教示発話 $O$ を認識する. ただし，ここでは正しい言語モデルが得られていると は限らないため, 単語分割の情報は破棄した $n$-best の 認識文字列 $\boldsymbol{S}_{1: N}^{\prime}$ を得る。

$$
\boldsymbol{S}_{1: N}^{\prime}=\operatorname{argmax} P\left(\boldsymbol{S}_{1: N}^{\prime} \mid \boldsymbol{O}, \mathcal{A}, \mathcal{L}\right)
$$


実験では，音声認識には Julius を用い，Julius 標準の 音響モデルを用いた .

\section{2. 言語モデル学習}

次に , 言語モデルのパラメータの推定を行う . 言語モ デルのパラメータ $\mathcal{L}$ は, 全教示発話 $\boldsymbol{O}$ を生成する確 率 $P(\boldsymbol{O} \mid \mathcal{A}, \mathcal{L})$ を最大化することで , 次式より得ること ができる .

$$
\begin{aligned}
\mathcal{L} & =\underset{\mathcal{L}}{\operatorname{argmax}} P(\boldsymbol{O} \mid \mathcal{A}, \mathcal{L}) \\
& =\underset{\mathcal{L}}{\operatorname{argmax}} \int P(\boldsymbol{S} \mid \mathcal{L}) P(\boldsymbol{O} \mid \boldsymbol{S}, \mathcal{A}) d \boldsymbol{S}
\end{aligned}
$$

しかし , $S$ での積分は, 全ての文字の組み合わせの和 を取ることを意味しており，直接計算することができ ない．乥こで，ここでは $P(\boldsymbol{O} \mid \boldsymbol{S}, \mathcal{A})$ は，一部の文字 列以外の確率は非常に小さく無視できると考え， $O$ の $n$-best の認識文字列 $\boldsymbol{S}_{1: N}^{\prime}$ のみを用い，図 3(b) のよう に音声認識モデルと切り離して考える . すなわち, 教 示発話 $\boldsymbol{O}$ を生成する確率を最大とする代わりに，教示 発話 $\boldsymbol{O}$ を認識した $n$-best $の$ 認識文字列 $\boldsymbol{S}_{1: N}^{\prime}$ から単 語列 $\boldsymbol{S}_{1: N}$ を生成する確率を最大とすることで, 言語

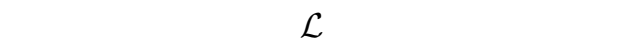

$$
\mathcal{L}, \boldsymbol{S}_{1: N}=\underset{\mathcal{L}, \boldsymbol{S}_{1: N}}{\operatorname{argmax}} P\left(\boldsymbol{S}_{1: N} \mid \boldsymbol{S}_{1: N}^{\prime}, \mathcal{L}\right)
$$

\section{3. 単語候補の選択}

言語モデルの学習と同樣に，以下の式か計算可能であ れば, 言語モデルと物体概念の双方を考慮した単語を 直接決めることができる .

$$
\begin{aligned}
\boldsymbol{W}^{w}=\underset{\boldsymbol{W}^{w}}{\operatorname{argmax}} & P\left(\boldsymbol{W}^{w} \mid \boldsymbol{O}, \mathcal{A}, \mathcal{L}, \boldsymbol{W}^{v, a, t}, \pi^{w}, \alpha\right) \\
=\underset{\boldsymbol{W}^{w}}{\operatorname{argmax}} \int & P(\boldsymbol{O} \mid \boldsymbol{S}, \mathcal{A}, \mathcal{L}) P\left(\boldsymbol{S} \mid \boldsymbol{W}^{w}, \mathcal{L}\right) \\
& \times P\left(\boldsymbol{W}^{w} \mid \boldsymbol{W}^{v, a, t}, \pi^{w}, \alpha\right) d \boldsymbol{S}
\end{aligned}
$$

ただし， $\boldsymbol{W}^{v, a, t}$ は，物体から得られる視覚・聴覚・触 覚情報である．しかし，この式においても $S$ で積分す ることが困難であるため，直接計算することができな い. 乥こで, ここでも $P(\boldsymbol{O} \mid \boldsymbol{S}, \mathcal{A})$ は, 一部の単語列以 外の確率は非常に小さく無視できると考え, 音声認識 の $n$-best から得た確率の高い単語列 $\boldsymbol{S}_{1: N}$ を利用し， 図 3(c)のように音声認識部と言語モデル学習部を切り 離して考える.すなわち, 教示発話 $\boldsymbol{O}$ と物体概念から 確率が最大となる $\boldsymbol{W}^{w}$ を選択するのではなく，音声認 識によって得られる $n$-best の単語列 $\boldsymbol{S}_{1: N}$ から物体概 念から生成される確率が最大となる単語 $\boldsymbol{W}^{w}$ を選択 する

$$
\begin{aligned}
\boldsymbol{W}^{w} & =\underset{\boldsymbol{W}^{w}}{\operatorname{argmax}} P\left(\boldsymbol{W}^{w} \mid \boldsymbol{O}, \mathcal{L}, \mathcal{A}, \boldsymbol{W}^{v, a, t}, \pi^{w}, \alpha\right) \\
& \approx \underset{\boldsymbol{W}^{w} \in \boldsymbol{W}_{1: N}}{\operatorname{argmax}} P\left(\boldsymbol{W}^{w} \mid \boldsymbol{W}^{v, a, t}, \pi^{w}, \alpha\right)
\end{aligned}
$$

ただし， $\boldsymbol{W}_{1: N}$ は $\boldsymbol{S}_{1: N}$ を単語へ分割して BoW 表現 へと変換したものである .ここで重要なことは，この
$\boldsymbol{W}^{w}$ は音声認識や物体概念から独立に生成されたもの ではなく，双方の結果を考慮した単語情報である点で ある．すなわち，音声認識が曖昧であり，“ぬいえぐる み”か“ぬいぐるみ”かか暧昧であつたとしても，ロボッ 卜が見ているものがぬいぐるみであり，光れが“ぬい ぐるみ”という単語で表現されることを知っていれば， 正しく“ぬいぐるみ”を選択することが可能となる．

\section{4. 物体概念形成}

以上の手順により，各物体に与えられた音声認識と物 体概念を考慮した単語情報 $\boldsymbol{W}^{w}$ を得ることができる． 物体概念は, 図 2 から, 音声認識部, 言語モデル学習 部, 単語生成部分を切り離し, 図 3(d) のモデルとし て学習を行う. 学習は, 全物体のマルチモーダル情報 $\boldsymbol{W}^{v}, \boldsymbol{W}^{a}, \boldsymbol{W}^{t}, \boldsymbol{W}^{w}$ を生成する確率を最大とするパラ メータ $\theta, \beta^{v}, \beta^{a}, \beta^{t}, \beta^{w}$ を求めることに相当し，本論 文ではギブスサンプリングを用いてパラメータを推定 する

$\mathcal{L}$ の初期值として全ての音節が等確率で出現する音節モ デルを用い，以上の手順を収束するまで繰り返すことで パラメータを推定する .これにより音声認識と物体概念 の双方が影響し合い，音声認識と物体概念の精度の向上 が期待できる.以降, 言語モデル学習, 物体概念形成, 学 習アルゴリズムの詳細について述べる .

\section{3. 言語モデル学習}

言語モデルは得られた認識結果を単語へ分節化するこ とで得ることができる.単語の分節化は，得られた認識 文字列 $\boldsymbol{S}^{\prime}$ を分節化し，単語列 $\boldsymbol{S}=\left\{w_{1}^{w}, w_{2}^{w}, \cdots\right\}$ が発生 する確率を最大とするパラメータ $\mathcal{L}$ を学習することで実 現できる .

$$
\mathcal{L}, \boldsymbol{S}=\underset{\mathcal{L}, \boldsymbol{S}}{\operatorname{argmax}} P\left(\boldsymbol{S} \mid \boldsymbol{S}^{\prime} \mathcal{L}\right)
$$

本論文では，このような教師なし形態素解析が可能な NPYLM を用い単語の分割を行うことで, 音声認識の言 語モデルの学習を行う.

\section{3-1 Hierarchical Pitman-Yor Language Model}

Hierarchical Pitman-Yor Language Model (HPYLM) は , 階層 Pitman-Yor 過程を用いた , $n$-gram 言語モデルであ る. HPYLM では, 文脈 $h$ の後に単語 $w$ が続く確率は以 下のようになる

$$
\begin{aligned}
p(w \mid h)=\frac{c(w \mid h)-d \cdot t_{h w}}{\theta+\sum_{w} c(w \mid h)} & \\
& +\frac{\theta+d \cdot \sum_{w} t_{h w}}{\theta+\sum_{w} c(w \mid h)} p\left(w \mid h^{\prime}\right)
\end{aligned}
$$

ただし , $h^{\prime}$ は $(n-1)$-gramの文脈である.よって, $p\left(w \mid h^{\prime}\right)$ は $h$ より一つ短い文脈での単語 $w$ か続く確率であり, 再 帰的に計算される．また， $c(w \mid h)$ は文脈 $h$ での単語 $w$ 
の発生回数であり, $t_{h w}$ は, $c(w \mid h)$ のうち, 文脈 $h^{\prime}$ から $w$ が発生した回数である.$d$ と $\theta$ は，Pitman-Yor 過程の ハイパーパラメータである.

\subsection{Nested Pitman-Yor Language Model}

前節の HPYML では, 単語ユニグラムの場合 , 式 (10) の $p\left(w \mid h^{\prime}\right)$ は単語辞書が与えられていれば,語彙数の逆数 を設定すればよい．しかし，ここでは辞書はあらかじめ用 意されていないため, 教示発話内の全ての部分文字列が 単語となる可能性があり，計算することが困難である。光 こで, 単語ユニグラムの基底測度として, 文字 HPYLM を使用する .これは, 単語 HPYLM の基底測度に文字 HPYLM が埋め込まれているモデルであるため, Nested Pitman-Yor Language Model(NPYLM) と呼ばれている . この NPYLM では , ブロック化ギブスサンプリングと動 的計画法により高速に単語の分割が可能である。

\section{4. 物 体 概 念形成}

ロボットは実際に物体を観察して得られるマルチモー ダル情報と，教示発話から得られる単語情報をカテゴリ 分類することで概念の形成を行う . 图 3(d) がマルチモー ダル LDA のグラフィカルモデルである $\cdot w^{v}, w^{a}, w^{t}$, $w^{w}$ は光れ帒れ視覚情報, 聴覚情報, 触覚情報, 単語情報 を示している.また $z$ は物体のカテゴリを表している.さ らに, $w^{v}, w^{a}, w^{t}, w^{w}$ は，光れ光れ $\beta^{v}, \beta^{a}, \beta^{t}, \beta^{w}$ をパラメータとする多項分布から発生する.これらの多 項分布は，弚れ光れ $\pi^{*}$ をパラメータとするディリクレ 事前分布に従う．また，カテゴリ $z$ の出現確率分布を表 す多項分布のパラメータを $\theta$ とする.このパラメータは， ハイパーパラメータ $\alpha$ により決まるディリクレ事前分布 に従う.物体の分類は，これらのモデルのパラメータを 学習データから推定することに相当する

\section{$4 \cdot 1$ マルチモーダル情報}

マルチモーダル情報は , 図 4 に示したロボットにより 取得した こここでは, ロボットが取得するマルチモーダ ル情報 (視覚・聴覚・触覚・単語情報) の詳細について 述べる。

視覚情報 ロボット (図 4) はアームの先に CCD カメラ と深度センサを搭載しており，物体を観察することで 得られる画像を視覚情報として利用する(図 5(a)) 。

画像は，物体の正面を $0^{\circ}$ とし，アームを $-30^{\circ}$ か ら $30^{\circ}$ まで $10^{\circ}$ ずつ動かし，合計 7 枚取得する．し かしこのままでは画像に背景が含まれてしまうため， 深度センサから得られるポイントクラウドに対して RANSAC[Fischler 81] によりロボット前方の平面を テーブルの天板として検出し , 弚の上に存在する一定以 上大きい点群を物体として切り出しを行う.各画像から 抽出する特徵量として, Dense Scale Invariant Feature

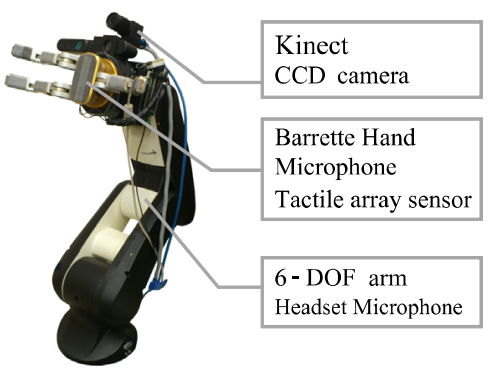

図 4 ロボットプラットフォーム

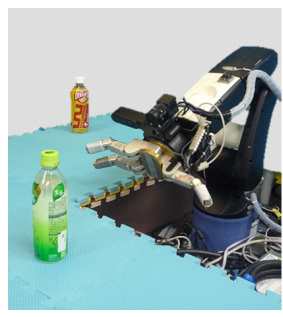

(a)

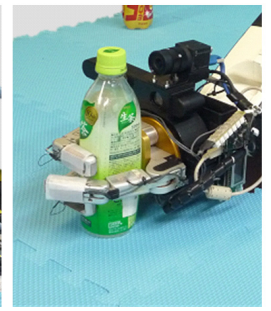

(b)

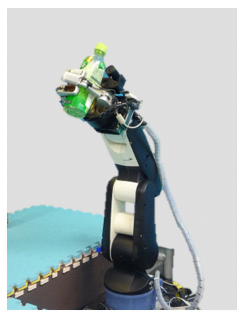

(c)
図 5 (a) 視覚情報の取得，(b) 触覚情報の取得，(c) 聴覚情報の取得

Transform (DSIFT) [Vedaldi 10] を用いる . 局所的な特 徵である SIFT[Lowe 04] がガウシアンピラミッドを用 いて特徵点を検出するのに対して，DSIFT ではグリッ ドサンプリングにより特徵点を求めている. DSIFTに より，1 つの画像から多数の特徵べクトルを得ること ができる.しかし , 特徵ベクトルの数は画像により異 なるため, このままでは物体の特徵量としては扱いに くい.

そのため, これらの特徵ベクトルは, 500 の代表べ クトルによりベクトル量子化することで, 500 次元の ヒストグラムとする .

触覚情報 触覚情報の取得には, アームに取り付けられ たバレットハンドと，弚のハンドに取り付けられた触 覚アレイセンサーを用いる(図4).

触角アレイセンサーは 162 個のセンサーから構成さ れており，ロボットか実際に物体を把持することで, 得 られるセンサーの情報から触覚特徵量を計算する . 図 5(b)のように，ロボットが実際に物体を把持すること で得られるセンサーの時系列データの近似を行い, 光 の近似パラメータを各センサーの特徵ベクトルとして 扱う [中村 10] . 実験では, 1 つの物体につき 5 回把持 することで得られる $810(=162 \times 5)$ 個の特徵べクトル を用いた .

さらに，この特徵べクトルをべクトル量子化するこ とで, 15 次元のヒストグラムを触覚情報として用いる . 聴覚情報

図 5(c)のように，ロボットは物体を持ち上げ前後に 各 6 回ずつ合計 12 回振ることで, 兴の際に発生する 


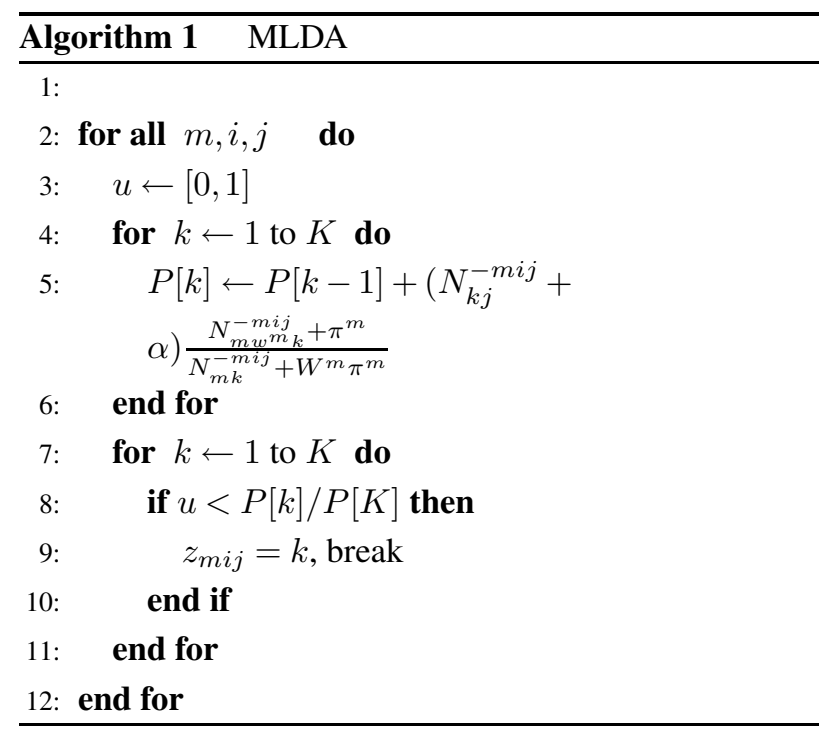

音を聴覚情報に用いる．実験では，振る直前から 12 回 振り終わった時点までの, 約 30 秒の音を用いた .

取得した音声信号はフレームに分割され，フレーム ごとに 13 次元の MFCC(Mel-Frequency Cepstrum Coefficient) を計算する .これにより，各フレームは 13 次 元の特徵ベクトルとなる . 最終的にこの特徵ベクトル も, ベクトル量子化を行い, 50 次元のヒストグラムと する .

単語情報 ロボットが物体を観察している間に, ユーザ が各物体の特徵を音声にて教示する . 3 章で述べたよ うに, ロボットは認識された音節列を，教師なし形態 素解析を行い単語へと分割する.最終的に, 単語の出 現頻度を表すヒストグラムを単語情報として用いる． 実験では, マルチモーダル情報は次の手順で取得した . ま ずューザがロボットの前に物体を置く．ロボットは，物 体を検出すると自動的に視覚, 触覚, 聴覚情報を順に取 得する.ユーザはロボットが動いている間に , 物体の特 徵を音声にて教示する.すなわち，ここではロボットが 視覚・聴覚・触覚情報を取得するために動作している間 は, 同一の物体の情報を取得していることを仮定してい る.また，ユーザの教示発話は，物体の特徵を教示すると いった制限のみで, 言い回しなどの制限は設けていない .

\section{$4 \cdot 2$ 物体概念の学習}

物体の分類は, 図 3(d) のグラフィカルモデルのパラ メータを, ロボットが取得したマルチモーダル情報を用 いて学習することに相当する . パラメータの学習にはギ ブスサンプリングを用いる . ギブスサンプリングでは , $j$ 番目の物体のモダリティ $m$ の情報の $i$ 番目に割り当てら れるカテゴリ $z_{m i j}$ を, $\theta, \beta^{m}$ を周辺化した条件付確率

$$
\begin{aligned}
& p\left(z_{m i j}=k \mid \boldsymbol{z}^{-m i j}, \boldsymbol{w}^{m}, \alpha, \pi^{m}\right) \\
& \propto\left(N_{k j}^{-m i j}+\alpha\right) \frac{N_{m w^{m} k}^{-m i j}+\pi^{m}}{N_{m k}^{-m i j}+W^{m} \pi^{m}}
\end{aligned}
$$

からサンプリングする.ただし,$W^{m}$ はモダリティ $m$ の
情報の次元数である.さらに, $N_{m w^{m} k j}$ を $j$ 番目の物体 のモダリティ $m$ の情報が $w^{m}$ となり，かつカテゴリ $k$ が 割り当てられた回数とすると， $N_{m w^{m} k}, N_{k j}, N_{m k}$ は以 下のようになる .

$$
\begin{aligned}
N_{m w^{m} k} & =\sum_{j} N_{m w^{m} k j} \\
N_{k j} & =\sum_{m, w^{m}} N_{m w^{m} k j} \\
N_{m k} & =\sum_{w^{m}, j} N_{m w^{m} k j}
\end{aligned}
$$

つまり, $N_{m w^{m} k}$ は全物体のモダリティ $m$ の情報 $w^{m}$ に カテゴリ $k$ か割り当てられた回数を， $N_{k j}$ は $j$ 番目の物 体全ての情報に，カテゴリ $k$ が割り当てられた回数を， $N_{m k}$ は, 全ての物体のモダリティ $m$ の情報に , カテゴ リ $k$ か割り当てられた回数を表している．また，式 (11) 内の除算の添字は，光の情報を除外していることを意味 している．すなわち， $\boldsymbol{z}^{-m i j}$ は, $j$ 番目の物体のモダリ ティ $m$ の $i$ 番目の情報へ割り当てられたカテゴリ $z_{m i j}$ を 取り除いた残りである .

ギブスサンプリングでは, 各物体 $j$ のモダリティ $m$ の $i$ 番目の情報へのカテゴリの割り当てを，式 (11)に従い サンプリングを行う (Algorithm 1) .これを繰り返すこと で， $N_{*}$ がある值 $\bar{N}_{*}$ へと収束する.最終的に , パラメー 夕の推定值 $\hat{\beta}_{w^{m} k}^{m}, \hat{\theta}_{k j}$ は以下のようになる.

$$
\begin{aligned}
\hat{\beta}_{w^{m} k}^{m} & =\frac{\bar{N}_{m w^{m} k}+\pi^{m}}{\bar{N}_{m k}+W^{m} \pi^{m}} \\
\hat{\theta}_{k j} & =\frac{\bar{N}_{k j}+\alpha}{N_{j}+K \alpha}
\end{aligned}
$$

\section{$4 \cdot 3$ 単語候補の選択}

提案するマルチモーダルカテゴリゼーションの有効性 は，物体のカテゴリ分類だけでなく，あるセンサ情報を 得ることによって他のセンサ情報を推測することができ る点にもある．つまり，物体を見ることによって，物体 の硬さ，乥れが音を出すかどうか，またどのような音を 出すか, さらにどのような単語で表現可能かなどの情報 を推測することができる．これを利用することで，物体 概念から単語が発生する確率である式 (8) を計算するこ とができ， $n$-best の認識文字列から得られた単語候補の 中から物体を最も表現する単語を選択することができる． 物体の視覚・聴覚・触覚情報 $\boldsymbol{w}^{v}, \boldsymbol{w}^{a}, \boldsymbol{w}^{t}$ が与えられた際 に，ある単語情報 $w^{w}$ が発生する確率は次のようになる．

$$
\begin{aligned}
& p\left(w^{w} \mid \boldsymbol{w}^{v}, \boldsymbol{w}^{a}, \boldsymbol{w}^{t}\right) \\
& \quad=\int \sum_{z} p\left(w^{w} \mid z\right) p(z \mid \theta) p\left(\theta \mid \boldsymbol{w}^{v}, \boldsymbol{w}^{a}, \boldsymbol{w}^{t}\right) d \theta
\end{aligned}
$$

ここで $p\left(\theta \mid \boldsymbol{w}^{v}, \boldsymbol{w}^{a}, \boldsymbol{w}^{t}\right)$ は， $\hat{\beta}_{w^{m} k}^{m}$ を固定し，式 (11)に よるサンプリングにより再計算することで決定する . 


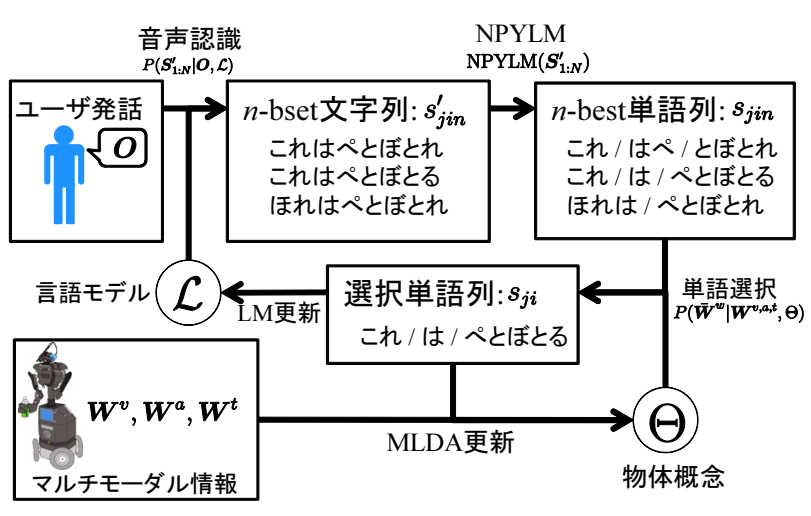

図 6 提案アルゴリズム概要

\section{5. 学習アルゴリズム}

NPYLM により，認識した音声を教師なしで形態素解 析し，言語モデルを学習することが可能となり，さらに MLDA により物体概念を形成することが可能となった． NPYLM と MLDA を，2 章で述べたモデルへ適用する ことで, 物体概念と言語モデルの相互学習が可能となる． 以下が, 提案する学習アルゴリズムであり, 図 6 がアル ゴリズムの概要図である .

(1) ロボットは言語的な知識を持たないことを前提と しているため，まず言語モデル $\mathcal{L}$ は全音節が等確率 で出現する音節モデルとし, 全教示発話 $\boldsymbol{O}$ を認識し 文字列 $S_{0}^{\prime}$ を得る .ただし，ここでの言語モデルと は Julius の言語モデルである .

$$
\boldsymbol{S}_{0}^{\prime} \sim P\left(\boldsymbol{S}_{0}^{\prime} \mid \boldsymbol{O}, \mathcal{A}, \mathcal{L}\right)
$$

次に， $\boldsymbol{S}_{0}^{\prime}$ NPYLM により単語列 $\boldsymbol{S}_{0}$ に分節化す ることで, 言語モデル $\mathcal{L}$ を計算する .

$$
\mathcal{L}, \boldsymbol{S}_{0} \sim \operatorname{NPYLM}\left(\boldsymbol{S}_{0}^{\prime}\right)
$$

ただし，NPYLM $(\cdot)$ は，NPYLM により，与えられ た文字列を単語に分節化し，言語モデルを計算する ことを意味している。

(2) $l=1$ とし，以下を収束するまで繰り返す.

i $j$ 番目の物体に与えられた $i$ 個目の教示発話 $o_{j i}$ を言語モデル $\mathcal{L}$ にって認識し，N-best の認識文 字列 $\boldsymbol{s}_{j i 0}^{\prime}, \cdots, \boldsymbol{s}_{j i N}^{\prime}$ を得る .

$$
\begin{aligned}
& \text { for all } i, j \\
& \qquad \boldsymbol{s}_{j i 0}^{\prime}, \cdots, \boldsymbol{s}_{j i N}^{\prime} \sim P\left(\boldsymbol{s}^{\prime} \mid o_{j i}, \mathcal{L}\right)
\end{aligned}
$$

認識された文字列 $s_{j i n}^{\prime}$ から NPYLMにより分割を 行うことで, 各文字列を単語列 $s_{j i n}$ へと変換する.

$$
\mathcal{L}, \boldsymbol{S}_{1: N}=\operatorname{NPYLM}\left(\boldsymbol{S}_{1: N}^{\prime}\right)
$$

ただし， $\boldsymbol{S}_{1: N}$ と $\boldsymbol{S}_{1: N}^{\prime}$ は光れ光れ，全物体の単語 列の集合と，認識された文字列の集合であり，次
のようになる .

$\boldsymbol{S}_{1: N}=$

$$
\left\{\boldsymbol{s}_{j i n} \mid 1 \leq j \leq J, 1 \leq i \leq I_{j}, 1 \leq n \leq N\right\}
$$

$\boldsymbol{S}_{1: N}^{\prime}=$

$$
\left\{\boldsymbol{s}_{j i n}^{\prime} \mid 1 \leq j \leq J, 1 \leq i \leq I_{j}, 1 \leq n \leq N\right\}
$$

$I_{j}$ は $j$ 番目の物体に与えられた教示発話の総数で ある.また， $s_{j i n}$ から単語の出現順序を取り除き BoW 表現へと変換したものを $\overline{\boldsymbol{w}}_{j i n}^{w}$ とし，弚の 集合を $\overline{\boldsymbol{W}}_{1: N}^{w}$ とする.以上のように， $j$ 番目の物 体に対する $i$ 番目のユーザの教示発話から $N$ 個の 単語列候補を得ることができる .

ii 以下, 全物体 $j(=1, \cdots, J)$ に関して繰り返す. a). $j$ 番目の物体の情報を除いたマルチモーダル 情報 $\boldsymbol{W}_{-j}^{v}, \boldsymbol{W}_{-j}^{a}, \boldsymbol{W}_{-j}^{t}, \overline{\boldsymbol{W}}_{-j}^{w}$ から物体概念の 形成を行う.

$\boldsymbol{\Theta}_{-j} \sim \operatorname{MLDA}\left(\boldsymbol{W}_{-j}^{v}, \boldsymbol{W}_{-j}^{a}, \boldsymbol{W}_{-j}^{t}, \overline{\boldsymbol{W}}_{-j}^{w}\right)$

ただし , 負の添字は, $\boldsymbol{W}^{v}, \boldsymbol{W}^{a}, \boldsymbol{W}^{t}, \overline{\boldsymbol{W}}^{w}$ から $j$ 番目の物体の情報を除いた残りを表している . また, $\operatorname{MLDA}(\cdot)$ は物体概念を学習することを 意味しており， $\boldsymbol{\Theta}_{-j}$ は MLDA によって学習さ れるパラメータを意味している .

b). $j$ 番目の物体に対する各発話の単語の候補 $\overline{\boldsymbol{w}}_{j i n}^{w}$ $(1 \leq n \leq N)$ の中から , $j$ 番目の物体に対する $i$ 番目の発話の単語として, 最も物体を表現して いる単語を選択し, 炎の単語 $\boldsymbol{w}_{j i}^{w}$ と単語列 $\boldsymbol{s}_{j i}$ を選択する。

for all $i$

$$
\begin{aligned}
& \hat{n}=\operatorname{argmax}_{n} p\left(\overline{\boldsymbol{w}}_{j i n}^{w} \mid \boldsymbol{w}_{j}^{v}, \boldsymbol{w}_{j}^{a}, \boldsymbol{w}_{j}^{h}, \boldsymbol{\Theta}_{-j}\right) \\
& \boldsymbol{w}_{j i}=\boldsymbol{w}_{j i \hat{n}} \\
& \boldsymbol{s}_{j i}=\boldsymbol{s}_{j i \hat{n}}
\end{aligned}
$$

この式において,$p\left(\overline{\boldsymbol{w}}_{j i n}^{w} \mid \boldsymbol{w}_{j}^{v}, \boldsymbol{w}_{j}^{a}, \boldsymbol{w}_{j}^{h}, \boldsymbol{\Theta}_{-j}\right)$ は, $j$ 番目の物体の情報 $\boldsymbol{w}_{j}^{v}, \boldsymbol{w}_{j}^{a}, \boldsymbol{w}_{j}^{h}$ から , 単語 $\overline{\boldsymbol{w}}_{j i n}^{w}$ が発生する確率を表しており，a)において学習 されたモデルと，式 (17) を用いて計算される .

iii 選択された単語列の集合 $S$ を用いて, 言語モデ ルの更新を行う．ただし， $S$ が最適な認識・分節 化結果であるとは限らないため $S_{0}$ も加え， $S$ と $\boldsymbol{S}_{0}$ から言語モデルのパラメータ $\mathcal{L}$ を再計算する .

$$
\mathcal{L}=\operatorname{LM}\left(\boldsymbol{S}, \boldsymbol{S}_{0}\right)
$$

$\operatorname{LM}(\cdot)$ は，与えられた単語列から言語モデルを計 算する関数であり，また

$$
\boldsymbol{S}=\left\{\boldsymbol{s}_{j i} \mid 1 \leq j \leq J, 1 \leq i \leq I_{j}\right\}
$$

である 


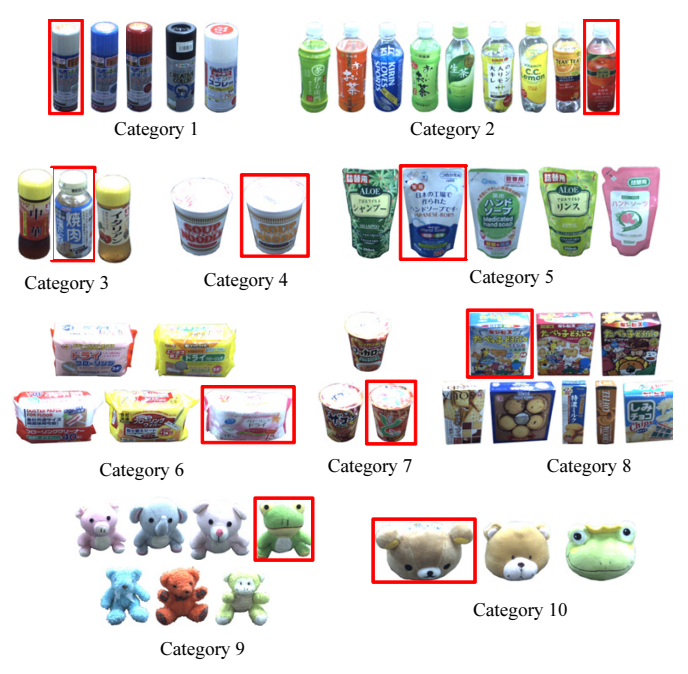

図 7 実験で使用した物体（矩形で囲まれている物体は単語の予測 実験で用いた物体である)

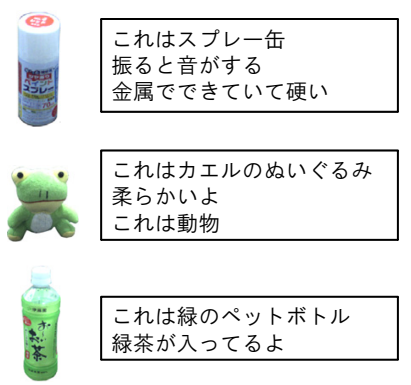

図 8 教示発話例

iv 収束していれば，選択された単語列の集合 $\boldsymbol{W}^{w}$ と，全物体のマルチモーダル情報を用いて MLDA のパラメータ $\Theta を$ を計算し，処理を終了する．

$$
\Theta \sim \operatorname{MLDA}\left(\boldsymbol{W}^{v}, \boldsymbol{W}^{a}, \boldsymbol{W}^{t}, \boldsymbol{W}^{w}\right)
$$

ただし，

$$
\boldsymbol{W}^{w}=\left\{w_{j i} \mid 1 \leq j \leq J, 1 \leq i \leq I_{j}\right\}
$$

である . 収束していなければ, $l=l+1$ とし iへ 戻り処理を繰り返す。

以上のように , 音声認識の言語モデルのパラメータと MLDA のパラメータを相互に計算することで, 最適な MLDA のパラメータ $\Theta$ と言語モデルのパラメータ $\mathcal{L} を$ 得ることができる．

\section{6. 実 験}

提案手法の有効性を検証するための実験を行った . 実 験では , 图 7 に示したペットボトルやぬいぐるみなど 10 カテゴリ 50 個の物体を使用した . ロボットは，これらの 物体を観察し，把持し，振ることで視覚・聴覚・触覚情 報を取得する．また，ユーザが各物体に関する特徵を口 ボットへ教示した音声を用い，弚の音声認識には Julius を使用した . 図 8 が実際にユーザがロボットへ教示した 発話の一部である . 実験では , 提案手法の性能を評価す るため, 以下の 3 つの手法で比較した .
A. 教示音声を音節認識した結果 $\boldsymbol{S}_{0}^{\prime}$ に対して，NPYLM により単語分割を行った単語列 $\boldsymbol{S}_{0}$ を用いて物体概 念を学習する手法

B. 言語モデルと物体概念を相互学習する手法 (提案 手法)

C. 教示発話を人手で書き起こして得られた誤りのな い文字列 $\boldsymbol{S}_{\text {correct }}$ に対して，NPYLM により単語分 割を行い, 弚の単語列を用いて物体概念を学習する 手法

すなわち，手法 A がベースラインであり，これまで我々 が用いてきた手法である.手法 B が本論文での提案手 法であり，手法 Cが本手法における限界性能であると考 えることができる．また，提案手法では， $N=10$ とし， 10-best の認識結果を使用した . 学習は，4.1 節で述べた 方法で图 7 の物体から取得した視覚・聴覚・触覚情報と， 各手法で計算した単語情報を用いて行った。

提案手法と従来手法の大きな違いは言語モデルの学習 の有無であるため，本実験では言語モデルの性能の評価 に焦点を当てた．マルチモーダル情報を利用することの 有効性に関しては, 文献 [中村 08, Nakamura 12, 中村 13] を参照されたい .

\section{1 教示発話の認識精度}

まず，提案手法 (手法 B) において図 7 の全ての物体 から取得したマルチモーダル情報と人からの教示発話を 用いて物体概念と言語モデルの学習を行った .ここでは 獲得された言語モデルを，光れぞれの手法の音声認識性 能で比較した . 手法 A と手法 B では同じ学習データを用 いて物体概念を形成しているが，手法 $\mathrm{A}$ は従来手法であ り言語モデルの学習は行っていない, 一方, 提案手法で ある手法 B は，提案アルゴリズムにより物体概念と言語 モデルを相互に学習している . 手法 C は人手による書き 起こしであるため，手法 Cで使用した文字列 $\boldsymbol{S}_{\text {correct }}$ を 正解として , 手法 A と手法 B の音声認識性能を正解との 音節の一致率で評価した .ここでは, 文字列 $s_{1}$ と $s_{2}$ が 与えられた際の，音節の一致率を以下のように定義する .

$$
C\left(s_{1}, s_{2}\right)=1-\frac{\operatorname{LS}\left(s_{1}, s_{2}\right)}{\max \left(\operatorname{len}\left(s_{1}\right), \operatorname{len}\left(s_{2}\right)\right)}
$$

ただし， LS $\left(s_{1}, s_{2}\right)$ は 2 つの文字列 $s_{1}, s_{2}$ のレーベンシュ タイン距離を表し, len $(s)$ は文字列 $s$ の長さを表してい る.また $\max (\cdot, \cdot)$ は 2 つの值のうち大きい方を返す関 数である.すなわち，この式は, 文字列が完全に一致し た場合は 1 となり，一致しない音節が増えると(レーべ ンシュタイン距離が長くなると)0 に近くなる文字列の一 致度を表している.この式を用いて，正解音節列と各手 法において認識された音節列の一致度を計算することで， 各手法の音節の認識精度を得ることができる . 各手法に おける全教示発話の音節の認識精度の平均が図 9 である. この図において，手法C は正解文字列を用いているため， 認識精度が $100 \%$ となっている．手法 A では，音節認識 


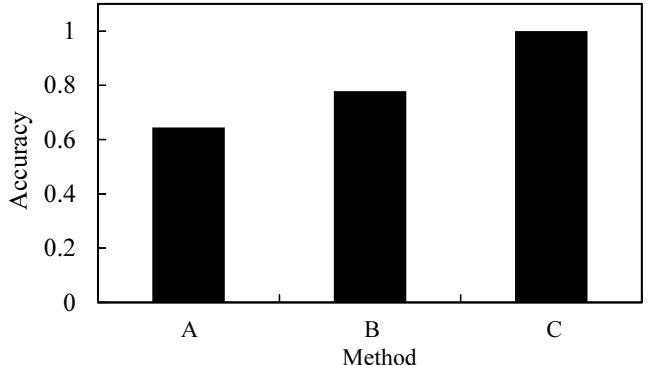

図 9 各手法における音節認識精度

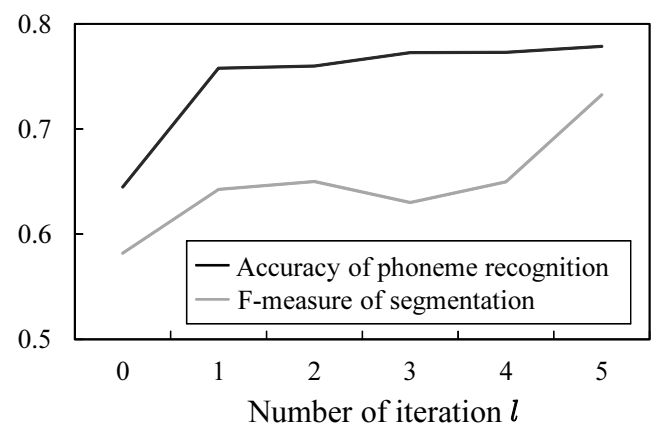

図 10 アルゴリズムの繰り返し回数に対する音節認識精度と 分節化精度

のみしか用いていないため $64 \%$ と最も低い値となった . 一方，提案手法である手法 B では，言語的な知識を持た ない状態から学習しているにもかかわらず, 手法 A に比 べ $10 \%$ 以改善していることが分かる .すなわち，提案 手法によってロボットは , 物体概念と言語モデルを相互 に繰り返し学習することで, より正しい言語モデルを獲 得できていることを意味している．

また，図 10 の黑線が，横軸を提案アルゴリズムの繰り 返し回数 $l$ とした場合の, 提案手法における音節の認識 精度である $. l=0$ の場合は, 提案手法を適用する前であ り，手法 A による認識精度を意味している．弚の後，学 習が進むことで認識精度が向上し,$l=2$ 以降では緩やか であるが単調増加していることが分かる．これは，物体 概念の学習と言語モデルの学習を相互に繰り返し行うこ とで, 言語モデルが精緻化していることを意味している .

\section{$6 \cdot 2$ 教示発話の単語分割精度}

次に, 単語への分節化の性能を評価した . 分節化の正 解として , 教師あり形態素解析 mecab[工藤 05] を用いて 誤りのない教示発話を単語へと分割し, 誤った分割がな された箇所を人手により修正したものを用いた．しかし， 認識された音節列には認識誤りや，脱落，挿入等が含ま れているため，単純に文節化の精度を計算することはで きない，光こで，正解の音節列と認識された音節列に対 して DP マッチングにより音節の対応を見つけ，表 1 の ように評価した .この表は，正解音節列「あいうえ」を 「あ/う/え」と分節化するのを正解として，認識された 誤りを含む音節列「ああうえ」を分節化した結果「あ/あ/ うえ」となった場合を評価した例である「「/」は単語の切 れ目を表している.単語の切れ目を正しく推定できた箇
表 1 分節化の評価例

\begin{tabular}{|c|ccccccc|}
\hline & (a) & (b) & (c) & (d) & (e) & (f) & (g) \\
\hline 正解音節列 : & あ & $/$ & い & & j & $/$ & え \\
認識音節列 : & あ & $/$ & あ & $/$ & j & & え \\
\hline 評価 : & TN & TP & TN & FP & TN & FN & TN \\
\hline
\end{tabular}

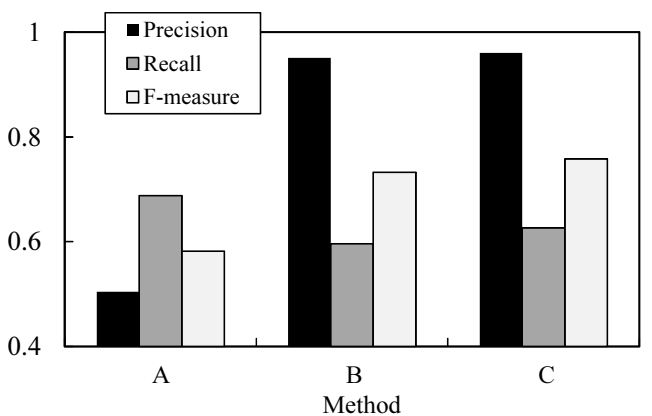

図 11 分節化の Precision, Recall, F-measure

所 (表 1(b)) をTP(True Positive), 誤って切れ目だと推定 した箇所 (表 1(d)) を FP(False Positive), 正しく切れ目 ではないと推定できた箇所 (表 1(a)(c)(e)(g)) をTN(True Negative), 誤って切れ目ではないと推定した箇所(表 1(f)) を FN(False Negative) とした . 最終的に , 各手法における 全教示発話に対する評価から，分節化の Precision, Recall, $\mathrm{F}$ 値を乥れ光れ以下のように計算した .

$$
\begin{aligned}
P & =\frac{N_{T P}}{N_{T P}+N_{F P}} \\
R & =\frac{N_{T P}}{N_{T P}+N_{F N}} \\
F & =\frac{2 R P}{R+P}
\end{aligned}
$$

ただし， $N_{T P}, N_{F P}, N_{F N}$ はとれ㶢れ，全教示発話内の $\mathrm{TP}, \mathrm{FP}$, FN と評価された箇所の総数である.図 11 に結 果を示す .この結果より, 手法 A では, Precision は最も 低いが , Recall が最も高くなっている .これは , 音節の誤 認識により, 正しい単語の切れ目が見つけられず, 正解よ りも短い単語へ分節化する傾向があったためであると考 えられる，一方，提案手法である手法 B は，正解音節列 を用いている手法 C とほぼ同等の結果となった . Recall が手法 A よりも低くなっているが，これは「おちゃの/ ペっとぼとる」のように, 助詞が正しく分節化できなかっ たためであり，学習データ量を増やし「おちゃは」や「お ちゃが」のような文節を含む教示発話があれば, 分節化 することが可能である . また , Precision は手法 A に比べ て 0.4 以上高く, F 值も約 0.15 高いため, 総合的にみて も提案手法が有効であるといえる.

さらに, 図 10 の灰色の線が, 横軸を提案アルゴリズ ムの繰り返し回数 $l$ とした時の $\mathrm{F}$ 值である . サンプリン グによって学習しているため，多少の上下は見られるが， $l$ か増加するにつれて F 値も上昇していることが分かる . この結果からも，提案手法が有効に働いていることが分 かる. 


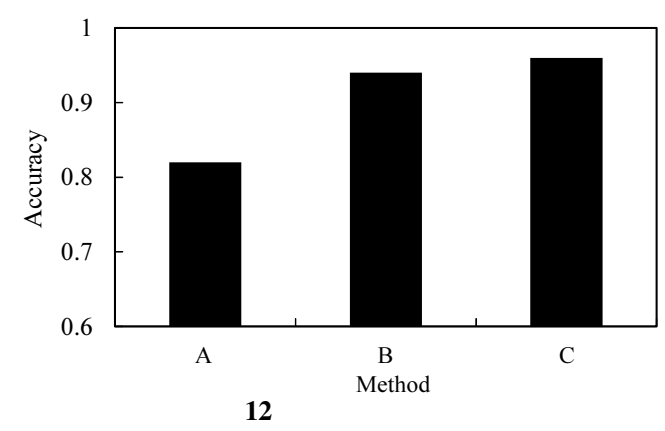

$6 \cdot 3$ 物体概念の評価

各手法によって最終的に得られた物体概念の評価を行っ た．図 7 の分類を正解とし評価した．正解の分類は被験 者に実際に分類してもらい，被験者間のばらつきが最も 少なかった分類である [中村 13] . 分類精度は以下の式よ り計算した。

$$
A c c=\frac{1}{J} \sum_{j} \delta\left(c_{\mathrm{MLDA}}(j), c_{\mathrm{correct}}(j)\right)
$$

ただし，Jは物体数であり， $c_{\mathrm{MLDA}}(j)$ と $c_{\mathrm{correct}}(j)$ は光 れぞれ， $j$ 番目の物体の分類されたカテゴリと，正解と なるカテゴリの ID である . $\delta(a, b)$ はデルタ関数であり， $a=b$ の時に $1, a \neq b$ の時に 0 となる関数である .

図 12 が各手法での分類精度である.この図より,手法 A に比べて，手法 B では $10 \%$ 以上精度が向上しており， 正解音節列を用いた手法 C と比較してもほぼ同等の結果 となっている．以上のように，提案手法では，物体概念 が教示発話の認識や単語分割精度を改善するだけではな く, 改善された音声認識や単語分割が物体の分類精度を 改善していることも分かる.

\section{4 単語の予測実験}

次に，物体のマルチモーダル情報から未観測の情報で ある単語の予測を行った . 図 7 の矩形で囲まれた物体を 末学習の認識用物体として用い, 残りの物体を学習用物 体とした．まず，学習用物体から取得したマルチモーダ ル情報と，これらの物体に与えられた教示発話から，手 法 A と手法 B により学習を行った . 次に，認識用物体 のマルチモーダル情報のみから, 兴の物体を表現する単 語の予測を行った . 予測は式 (17) を用い, 確率の高い 単語を予測結果として出力した .ただし，このままでは， 「です」や「これ」といった全ての物体の教示発話に含ま れている単語が高い確率で予測されてしまう. 弚れを避 けるため，TF-IDF (Term Frequency-Inverse Document Frequency）による重みづけを利用した [荒木 13] .

予測された上位 5 単語に関して，光の単語が光の物体 を正しく表現しているかを評価した，光の結果，手法 A では予測された単語のうち物体を正しく表現できている 単語は 40\%であった . 一方, 提案手法である手法 B では 68\%であった . どちらの手法であっても，誤って予測さ れた単語は学習時の音声の誤認識・単語の誤分割が原因
であると考えられる . 例えば,「ぬいぐるみ」という単語 の切り出しを誤り,「ぬ」を物体を表す単語として学習す ると，未学習のぬいぐるみを観測した際も「ぬ」を物体 を表現する単語として予測してしまう。しかし，提案手 法では音声の誤認識，単語の誤分割が低減したことによ り,より正しい単語の予測が可能となっている.

\section{7. ま め}

本論文では, ロボットが取得したマルチモーダル情報 と人からの教示発話を用いて, ロボットにより概念と言 語モデルを相互に学習する手法を提案した . ロボットは 言語知識を持たないことを想定し，人からの教示発話を 音節認識し，認識された音節列に対して NPYLM を適用 することで単語へと分割した．しかし，音節認識では認 識誤りが多く発生するため，正しい単語を得ることは困 難である．关こで，音声認識の $n$-best の認識結果を，認 識文字列の候補とし，关れらの文字列に対して NPYLM を適用することで，単語の候補を計算した .このようにし て得られた単語の候補から，ロボットが観測している物 体を最も表現している単語を選択した .さらに , 兴の選択 された単語から言語モデルを更新することで, 音声認識 精度を改善し，NPYLMによる教示発話の分節化の精度 も向上することができた .今後 , 我々がこれまで行ってき たオンラインマルチモーダルカテゴリゼーション [Araki 12] へこの手法を適用することで, よりインタラクティ ブに学習が可能なシステムを構築する予定である .

\section{$\diamond$ 参 考 文 献 $\diamond$}

[Araki 12] Araki, T., Nakamura, T., Nagai, T., Nagasaka, S., Taniguchi, T., and Iwahashi, N.: Online Learning of Concepts and Words Using Multimodal LDA and Hierarchical Pitman-Yor Language Model, in IEEE/RSJ International Conference on Intelligent Robots and Systems, pp. 1623-1630 (2012)

[Blei 03] Blei, D. M., Ng, A. Y., and Jordan, M. I.: Latent Dirichlet Allocation, Journal of Machine Learning Research, Vol. 3, pp. 9931022 (2003)

[Endres 09] Endres, F., Plagemann, C., Stachniss, C., and Burgard, W.: Unsupervised Discovery of Object Classes from Range Data Using Latent Dirichlet Allocation, in Robotics: Science and Systems (2009)

[Fei-Fei 05] Fei-Fei, L.: A Bayesian Hierarchical Model for Learning Natural Scene Categories, in IEEE Conference on Computer Vision and Pattern Recognition, pp. 524-531 (2005)

[Fergus 03] Fergus, R., Perona, P., and Zisserman, A.: Object Class Recognition by Unsupervised Scale-Invariant Learning, in IEEE Conference on Computer Vision and Pattern Recognition, Vol. 2, pp. 264-271 (2003)

[Fischler 81] Fischler, M. A. and Bolles, R. C.: Random sample consensus: a paradigm for model fitting with applications to image analysis and automated cartography, Communications of the ACM, Vol. 24, No. 6, pp. 381-395 (1981)

[Lallee 13] Lallee, S. and Dominey, P. F.: Multi-modal Convergence Maps: From Body Schema and Self-Representation to Mental Imagery, Adaptive Behavior, Vol. 21, No. 4, pp. 274-285 (2013)

[Lowe 04] Lowe, D. G.: Distinctive Image Features from ScaleInvariant Keypoints, International Journal of Computer Vision, Vol. 60, No. 2, pp. 91-110 (2004) 
[Mangin 13] Mangin, O. and Oudeyer, P.-Y.: Learning Semantic Components from Subsymbolic Multimodal Perception, in IEEE Third Joint International Conference on Development and Learning and Epigenetic Robotics, pp. 1-7 (2013)

[Mochihashi 09] Mochihashi, D., Yamada, T., and Ueda, N.: Bayesian Unsupervised Word Segmentation with Nested Pitman-Yor Language Modeling, in Proceedings of the Joint Conference of the 47th Annual Meeting of the ACL and the 4th International Joint Conference on Natural Language Processing of the AFNLP, Vol. 1, pp. 100-108 (2009)

[Nakamura 12] Nakamura, T., Araki, T., Nagai, T., and Iwahashi, N.: Grounding of Word Meanings in LDA-Based Multimodal Concepts, Advanced Robotics, Vol. 25, pp. 2189-2206 (2012)

[Natale 04] Natale, L., Metta, G., and Sandini, G.: Learning Haptic Representation of Objects, in IEEE International Conference on Intelligent Manipulation and Grasping (2004)

[Ogata 10] Ogata, T., Nishide, S., Kozima, H., Komatani, K., and Okuno, H.: Inter-Modality Mapping in Robot with Recurrent Neural Network, Pattern Recognition Letters, Vol. 31, No. 12, pp. 1560 1569 (2010)

[Ridge 10] Ridge, B., Skocaj, D., and Leonardis, A.: Self-supervised Cross-Modal Online Learning of Basic Object Affordances for Developmental Robotic Systems, in IEEE International Conference on Robotics and Automation, pp. 5047-5054 (2010)

[Rosch 99] Rosch, E.: Principles of Categorization, Concepts: Core readings, pp. 189-206 (1999)

[Roy 02] Roy, D. and Pentland, A.: Learning Words from Sights and Sounds: A Computational Model, Cognitive Science, Vol. 26, No. 1, pp. 113-146 (2002)

[Russell 00] Russell, R.: Object Recognition by a 'Smart' Tactile Sensor, in Australian Conference on Robotics and Automation (2000)

[Schneider 09] Schneider, A., Sturm, J., Stachniss, C., Reisert, M., Burkhardt, H., and Burgard, W.: Object Identification with Tactile Sensors Using Bag-of-Features, in IEEE/RSJ International Conference on Intelligent Robots and Systems, pp. 243-248 (2009)

[Sinapov 11] Sinapov, J. and Stoytchev, A.: Object Category Recognition by a Humanoid Robot Using Behavior-Grounded Relational Learning, in IEEE International Conference on Robotics and Automation, pp. 184-190 (2011)

[Sivic 05] Sivic, J., Russell, B. C., Efros, A. A., Zisserman, A., and Freeman, W. T.: Discovering Object Categories in Image Collections, in IEEE International Conference on Computer Vision, pp. 17-20 (2005)

[Smith 05] Smith, L. and Gasser, M.: The Development of Embodied Cognition: Six Lessons from Babies, Artificial Life, Vol. 11, No. 1-2, pp. 13-29 (2005)

[Vedaldi 10] Vedaldi, A. and Fulkerson, B.: VLFeat: An Open and Portable Library of Computer Vision Algorithms, in ACM International Conference on Multimedia, pp. 1469-1472 (2010)

[Wang 09] Wang, C., Blei, D., and Fei-Fei, L.: Simultaneous Image Classification and Annotation, in IEEE Conference on Computer Vision and Pattern Recognition, pp. 1903-1910 (2009)

[Wermter 04] Wermter, S., Weber, C., Elshaw, M., Panchev, C., Erwin, H., and Pulvermüller, F.: Towards Multimodal Neural Robot Learning, Robotics and Autonomous Systems, Vol. 47, No. 2, pp. 171-175 (2004)

[工藤 05] 工藤 拓 : MeCab: Yet another part-of-speech and morphological analyzer, http://mecab. sourceforge. net/ (2005)

[荒木 13] 荒木 孝弥, 中村 友昭, 長井 隆行 : ロボットによる才ン ライン語彙学習 : ロボットが一週間で学んだものとは?,2013 年 度人工知能学会全国大会 (第 27 回)，2G4-OS-19a-1 (2013)

[中村 08] 中村 友昭, 長井 隆行, 岩橋 直人 : ロボットによる物体 のマルチモーダルカテゴリゼーション, 電子情報通信学会論文誌 (D) , Vol. 91, pp. 2507-2518 (2008)

[中村 10] 中村 友昭, 西田 匡志, 長井 隆行 : 把持動作による物体 カテゴリの形成と認識, 情報処理学会全国大会, 5V-3 (2010)

[中村 13] 中村 友昭, 荒木 孝弥, 長井 隆行, 岩橋直人 : 階層ディリ クレ過程に基づくロボットによる物体のマルチモーダルカテゴリ ゼーション, 計測自動制御学会論文集, Vol. 49, No. 4, pp. 469-478 (2013)

[田口 10] 田口 亮, 岩橋 直人, 船越 孝太郎, 中野 幹生, 能勢 隆, 新
田 恒雄 : 統計的モデル選択に基づいた連続音声からの語彙学習， 人工知能学会論文誌, Vol. 25, No. 4, pp. 549-559 (2010)

〔担当委員 : 矢入 健久〕

2014 年 9 月 1 日 受理 


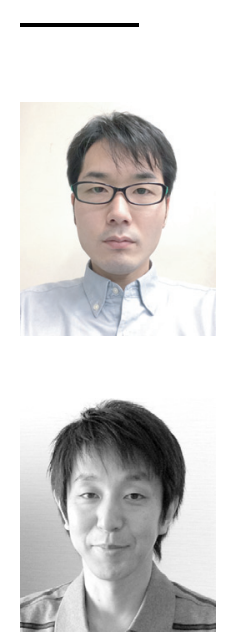

者 紹 介

中村 友昭(正会員)

2007 年電気通信大学電気通信学部電子工学科卒業 . 2009 年同大学院電気通信学研究科修士課程修了. 2011 年同大 学院博士課程修了. 博士 (工学) . 2011 年日本学術振興会 特別研究員 (PD) . 2013 年ホンダ・リサーチ・インスティ チュート・ジャパンリサーチャ. 2014 年電気通信大学情 報理工学研究科知能機械工学専攻助教. 知能ロボットに関 する研究に従事 .

信学会, IEEE 各会員.

\section{長井 隆行(正会員)}

1993 年慶應義塾大学理工学部電気工学科卒業. 1997 年同 大学院理工学研究科博士課程修了. 博士 (工学) . 1998 年 電気通信大学電子工学科助手. 2003 年カリフォルニア大 学サンディエゴ校客員研究員. 2004 年電気通信大学大学 院電気通信学研究科助教授、現在，同大大学院情報理工学 研究科准教授. 2011 年より玉川大学脳科学研究所特別研 究員を兼務. 知能システム, 知能ロボティクスに関する研 究に従事。日本ロボット学会, 情報処理学会, 電子情報通

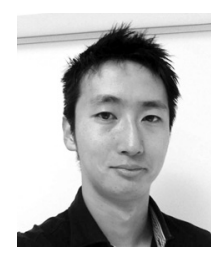

船越 孝太郎(正会員)

2000 年東京工業大学工学部情報工学科卒業. 2002 年同 大学大学院情報理工学研究科計算工学専攻修士課程修了。 2005 年同大学院博士課程修了.同年, 東京工業大学大学院 特別研究員. 2006 年より(株) ホンダ・リサーチ・インス ティチュート・ジャパンリサーチャ. 2013 年より同シニ ア・リサーチャ. 博士 (工学) . 自然言語理解, マルチモー ダル対話に関する研究に従事. 情報処理学会, 言語処理学 会, ヒューマンインタフェース学会, ACM SIGCHI 会員.

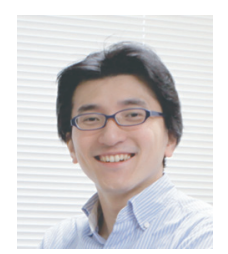

\section{谷口 忠大 (正会員)}

2006 年京都大学大学院工学研究科博士課程修了. 2005 年よ り日本学術振興会特別研究員 (DC2), 2006 年より同 $(\mathrm{PD})$. 2007 年より京都大学大学院情報学研究科にて (PD) 再任 2008 年より立命館大学情報理工学部助教, 2010 年より同 准教授 。個体と組織における記号過程の計算論的な理解や 共生社会に向けた知能情報学技術の応用研究についての研 究に従事. 博士 (工学, 京都大学) . 計測自動制御学会学 術奖励賞, システム制御情報学会学会賞奨励賞, 論文賞, 砂原賞などを受賞 . 計測自動制御学会, システム制御情報学会, 日本認知科学会, IEEE などの会員 .

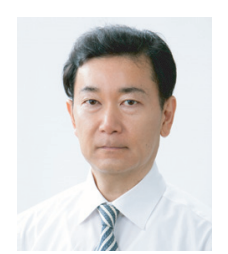

\section{岩橋 直人(正会員)}

1985 年慶應義塾大学理工学部計測工学科卒業. 1985 年 よりソニー (株) . 1990 1993 年 ATR 自動翻訳電話研究 所へ出向. 1998 より (株) ソニーコンピュータサイエン 又研究所. 2004 より (株) 国際電気通信基礎技術研究所. 2008 年より (独) 情報通信研究機構. 2014 年より岡山県 立大学情報工学部教授、機械学習, 知能ロボティクス, マ ルチモーダル対話システム, ロボットによるマルチモーダ ル言語獲得の研究に従事. 博士 (工学, 東京工業大学) . 人 工知能学会論文賞, Advanced Robotics Best Paper Award など受賞 . 日本認知科 学会, 電子情報通信学会, ACL などの会員.

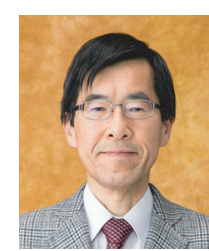

\section{金子 正秀}

1976 年東京大学工学部電子工学科卒業. 1981 年同大学院 工学系研究科博士課程修了. 工学博士. 国際電信電話株式 会社研究所主幹研究員, 東京大学大学院工学系研究科助教 授などを経て, 現在, 電気通信大学大学院情報理工学研究 科教授。顔画像情報処理, コンピュータ似颜絵師, ヒュー マンロボットコミュニケーション, 知能ロボティクス, 察 するインタフェースなどの研究に従事．電子情報通信学会， ボット学会, 日本顔学会, IEEE 各会員。 